\title{
Biosynthesis of L-Glutaminase by Streptomyces Variabilis ASU319 Isolated from Rhizosphere of Triticum Vulgaris
}

\author{
Mohamed Hemida. Abd-Alla ${ }^{1, *}$, El-Sayed. A. El-Sayed ${ }^{2}$, Abdel-Hamied. M. Rasmey ${ }^{3}$ \\ ${ }^{1}$ Botany and Microbiology Department, Faculty of Science, Assiut University, Egypt \\ ${ }^{2}$ Botany Department, Faculty of Science, Zagazig University, Egypt \\ ${ }^{3}$ Botany and Microbiology Department, Faculty of Science, Suez University, Egypt \\ *Corresponding author: mhabdalla2002@yahoo.com
}

Copyright (C) 2013 Horizon Research Publishing All rights reserved.

\begin{abstract}
Out of 210 actinomycetes isolates belonged to the genus Streptomyces recovered from rhizospheric soil of Triticum vulgaris, Zea mays and Vicia faba cultivated in Assuit and New Valley Governorates of Egypt, ten isolates were capable of producing high amounts of L-glutaminase enzyme. The most potent L-glutaminase producer isolate was Streptomyces $\mathrm{sp}$. ASU319 recovered from rhizosphere of Triticum vulgaris. The higher producer actinomycete isolate was identified by sequencing of $16 \mathrm{~S}$ rRNA as Streptomyces variabilis ASU319 and was deposited in the GenBank nucleotide sequence database under accession number KC145278. Factors affecting L-glutaminase production by the Streptomyces variabilis ASU319(KC145278) were examined and the results revealed that the maximum L-glutaminase value was obtained when the isolate cultivated in the production broth medium supplemented by glutamine $8 \mathrm{mg} / \mathrm{ml}$, adjusted at $\mathrm{pH}$ 4 and incubated at $35{ }^{\circ} \mathrm{C}$. These results suggest that L-glutaminase-producing Streptomyces variabilis ASU319 could be used as a plant growth promoting rhizobacteria by increasing the ammonia content in the rhizosphere soil across degradation of the agricultural wastes. Also this isolate can be used in both pharmaceutical and food industrial application for L-glutaminase production on commercial scale.
\end{abstract}

Keywords Streptomyces variabilis, Triticum vulgaris, 16S rRNA, L-glutaminase

\section{Introduction}

Microbial sources like actinomycetes are well recognized to produce a variety of chemical structures, several of which are most valuable pharmaceuticals, agrochemicals and industrial products like enzymes (1). Actinomycetes are considered to be preferred enzymes sources due to their production of extracellular enzymes. They act as decomposers of complex animal and plant materials resulting in release of simple substances, especially carbon and nitrogen which is easily utilized by other organisms, thus performing a vital role in life cycle. Many enzymes produced by actinomycetes and have been used as drugs like wise L-glutamine amidohydrolase (E.C. 3.5.1.2), commonly referred to as L-glutaminase, has received much attention with respect to its therapeutic and industrial applications. L-glutaminase is used as a flavor enhancer by increasing glutamic acid content in food through hydrolysis of L-glutamine to L-glutamic acid and ammonia. It also used in enzyme therapy for cancer especially for acute lymphocytic leukemia. Another important application of L-glutaminase is in biosensors to monitor the L-glutamine levels in body fluids. This technique is more applicable than previously used methods and characterized by its high specificity compared with cell based sensors in addition to its fast response. This has led to intensive use of glutaminase in clinical purposes especially that is derived from mammalian tissues (2). In 1993, Pseudomonas sp., recombinant glutaminase was patented for its activity against cancer and HIV virus therapy (3). L-glutaminase synthesis was well reported from various terrestrial microorganisms such as Escherichia coli, Pseudomonas species, Acinetobacter species, Bacillus species, Hansenula, Cryptococcus, Candida, Aspergillus oryzae and Beuveria bassiana (4). In addition to terrestrial sources, L-glutaminase activity was reported from few marine microorganisms such as Pseudomonas fluorescens, Micrococcus luteus, Vibrio cholerae and Beuveria bassiana (5). However, from the available literatures, it is found that information on L-glutaminase production from actinomycetes is still in the stage of infancy (6). Its commercial importance as anticancer and flavor enhancing agent demands not only the search for better yielding viable strains, but also economically viable bioprocesses for its large scale production (7). Different types of organisms were reported to produce glutaminase enzyme. However, the selection of the right organism is very critical to obtain high yield of the required enzyme (8). The purpose of this work was to isolate and characterize L-glutaminase-producing Streptomyces and optimized the 
culture conditions to increase the production of this enzyme.

\section{Materials and Methods}

\subsection{Isolation of Actinomycetes}

Starch casein agar and glycerol asparagine agar media supplemented with griseoflavin $(50 \mu \mathrm{g} / \mathrm{ml})$ and streptomycin $(50 \mu \mathrm{g} / \mathrm{ml})$ were used for isolation of 210 actinomycetes isolates from 100 rhizosphereic soil samples were collected from three crop plants (Triticum vulgaris, Zea mays and Vicia faba) cultivated in different locations of Assiut and New Valley Governorates, Egypt. The Streptomyces isolates were recovered by serially dilution method and the plates were rotated by hand for good dispersion of soil suspension and incubated at $28^{\circ} \mathrm{C}$ for $7-21$ days. Individual colonies were picked up, and sub cultured on fresh agar medium. The actinomycetes cultures were purified and transferred to agar slants of the same medium; incubated at $28^{\circ} \mathrm{C}$ for 5-7 days to achieve good sporulation, and then stored at $4^{\circ} \mathrm{C}$ in refrigerator.

\subsection{Detection Of L-Glutaminase Producing Actinomycetes}

Minimal glutamine agar medium was prepared and used for detection of L-glutaminase producing actinomycetes. Components of MGA $(\mathrm{g} / \mathrm{L})$ include $0.5 \mathrm{KCl} ; 0.5 \mathrm{MgSO}_{4} ; 1.0$ $\mathrm{KH}_{2} \mathrm{PO}_{4} ; 0.1 \mathrm{FeSO}_{4} ; 0.1 \mathrm{ZnSO}_{4} ; 0.5 \mathrm{NaCl} ; 10.0 \mathrm{~L}$-glutamine and supplemented with $0.012 \mathrm{~g}$ phenol red and $\mathrm{pH}$ adjusted at 6.8 , in which L-glutamine act as the sole carbon and nitrogen source and phenol red as $\mathrm{pH}$ indicator. The colour change of the medium from yellow to pink is an indication of the extra cellular L-glutaminase production by the colony. This colour change is due to change in the $\mathrm{pH}$ of the medium, as L-glutaminase causes the breakdown of amide bond in L-glutamine and liberates ammonia. All the actinomycetes isolates collected were streaked on minimal glutamine agar medium. After four days of incubation at $30^{\circ} \mathrm{C}$, the change of medium colour from yellow to pink around the colony indicating positive response. The secondary screening for the highly producer isolates was done by the same previously method but in liquid medium and the pink colour degree of the supernatant after filteration and centrifugation of the medium at $3000 \mathrm{rpm}$ for $15 \mathrm{~min}$ was measured at $540 \mathrm{~nm}$ using a visible spectrophotometer.

\subsection{Production of $L$-glutaminase in Submerged Culture}

One $\mathrm{ml}$ inoculum of the tested actinomycete isolate was inoculated in to $50 \mathrm{ml}$ of production medium which contains $(\mathrm{g} / \mathrm{L}): 1.0 \mathrm{KH}_{2} \mathrm{PO}_{4} ; 0.5 \mathrm{MgSO}_{4} ; 0.1 \mathrm{CaCl}_{2} ; 0.1 \mathrm{NaNO}_{3} ; 0.1$ tri sodium citrate; $0.5 \mathrm{NaCl} ; 10.0 \mathrm{~L}$-glutamine and 10.0 glycerol, $\mathrm{pH}$ 7. All the flasks were incubated at $28^{\circ} \mathrm{C}$ on an orbital shaking at $120 \mathrm{rpm}$ for $120 \mathrm{~h}$. The samples withdrawn were centrifuged at $3000 \mathrm{rpm}$ for $15 \mathrm{~min}$ and the clear supernatant was used for enzyme estimation.

\subsection{L-Glutaminase Activity}

The activity of glutaminase is determined by estimating the amount of ammonia liberated from glutamine. The amount of ammonia was measured by adding $100 \mu 1$ of the crude enzyme to $200 \mu 1$ Nessler's reagent and completed to 4 $\mathrm{ml}$ by distilled water. Absorbance was measured at $540 \mathrm{~nm}$ using a visible spectrophotometer. L-glutaminase activity is expressed in $\mu \mathrm{g}$ ammonia produced per one $\mathrm{ml}$ medium. The level of ammonia produced was estimated against the ammonia standard curve using ammonium sulphate.

\subsection{Morphological Characterization of Streptomyces ASU319}

\subsubsection{Colony Characterization}

The morphology of the strain was studied in tryptone yeast extract agar (ISP-1), oatmeal agar (ISP-3), starch agar with inorganic salts (ISP-4) and glycerol-asparagine agar (ISP-5). The production of the melanin was tested on peptone-yeast extract iron agar (ISP-6) and tyrosine agar (ISP-7). Colony morphology was recorded with respect to colour aerial mycelium, reverse side and diffusible pigment using an Inter-Society Color Council- National Bureau of Standards (ISCC-NBS) color chart (9).

\subsubsection{Microscopic Characterization}

The actinomycetes were slowly released at the intersection of medium to the cover slip. The plates were inoculated at $28 \pm 2^{\circ} \mathrm{C}$ for $4-8$ days. The cover slips were removed from the cultured medium and observed under the light microscope. The photomicroscopy was taken using Nikon microscope. Spore chain and spore surface ornamentation were examined by light and electron microscopy (10).

\subsubsection{Gram Staining}

The Gram stain was carried out on 3-4 days cultures according to the Hucker method (11).

\subsection{Physiological and Biochemical Characteristics}

Isomer of diaminopimelic acid was analysed by TLC (12). The physiological and biochemical characteristics were monitored according to standard methods of starch hydrolysis (13), cellulose hydrolysis (14), gelatin hydrolysis (15), casein hydrolysis (16), $\mathrm{H}_{2} \mathrm{~S}$ production (17), nitrate reduction (18), catalase production (19), milk peptonization and utilization of carbon and nitrogen sources (20).

\subsection{Identification of Streptomyces ASU319 Using 16S rRNA}

2.7.1. DNA isolation 
The locally isolated Streptomyces ASU319 was grown for 7 days on a starch agar slants at $30^{\circ} \mathrm{C}$. Two $\mathrm{ml}$ of a spore suspension were inoculated into the starch nitrate broth and incubated for 3 days on a shaker incubator at $200 \mathrm{rpm}$ and $30^{\circ} \mathrm{C}$ to form a pellet of vegetative cells. The preparation of total genomic DNA was conducted according to the method of Wittenberg (21).

\subsubsection{PCR Amplification}

The 16S rRNA encoding gene was amplified by the polymerase chain reaction (PCR) from purified genomic DNA usingthe Streptomyces specific PCR primers

StrepB, 5'- ACAAGCCCTGGAAACGGGT-3' (forward) and StrepF, 5'-ACGTGTGCAGCCCAAGACA-3' (reverse). The PCR amplification was performed by using Qiagen Proof-Start Tag Polymerase Kit (Qiagen, Hilden, Germany). The following substrates were combined in a total volume of $25 \mu \mathrm{l}$ including about $50 \mathrm{ng}$ of template DNA, $12.5 \mu \mathrm{PCR}$ Master Mix, 5 pmol $(0.5 \mu \mathrm{l})$ each of forward and reverse primers and the total reaction volume was completed by 11.5 $\mu l$ of water DNAase free water. This step is performed on the ice. The complete reaction mixture was incubated at automated thermocycler TC-3000 (Applied Bacteriology Laboratory, Botany Department, Assiut University, Assiut). The reaction conditions were: an initial denaturation at $95^{\circ} \mathrm{C}$ for $3 \mathrm{~min}, 35$ cycles of denaturation at $94{ }^{\circ} \mathrm{C}$ for $70 \mathrm{~s}$, annealing at $56^{\circ} \mathrm{C}$ for $40 \mathrm{~s}$, and extension at $72{ }^{\circ} \mathrm{C}$ for $130 \mathrm{~s}$. A final extension was conducted at $72^{\circ} \mathrm{C}$ for $370 \mathrm{~s}(21)$. PCR products were analyzed by electrophoresis on $1 \%(\mathrm{w} / \mathrm{v})$ agarose TBE-gels (Tris-base Boric EDTA-gel) and the gels were visualized and pictured under UV light. PCR products of about (1100 bp) were purified from gel with the QIAquick gel extraction kit (Qiagen, Hilden, Germany).

\subsubsection{DNA Sequencing}

Purified PCR products were sequenced by cycle sequencing with didesoxy mediated chain-termination (22). Sequencing was done by the Biovision Company, which sent it to the Gene Analysis Unit (Macrogene Inc., Seuol, Korea) Sequencer AB-13730. For sequencing the purified PCR products, the same primers StrepB (forward) and StrepF (reverse) were used. Sequences of the 16S rRNA of isolates were first analyzed using the advanced BLAST search program at the NCBI website: http:// www.ncbi.nlm.nih.gov/BLAST/ in order to assess the degree of DNA similarity. Multiple sequence alignment and molecular phylogeny was evaluated using CLUSTALW program (http://clustalw.ddbj.nig.ac.jp/top-ehtml). The phylogentic tree was displayed using the TREE VIEW program. Phylogenetic tree derived from 16S rRNA gene sequence was generated in comparison to $16 \mathrm{~S}$ rRNA gene sequences from different standard Streptomyces strains obtained from GenBank: S. variabilis NRRLB3984, S. labedae NBRC15864, S. griseorubens NBRC12780, S. erythrogriseus LMG19406, S. griseoincarnatus LMG19316, S. griseoflavus LMG19344, S. althioticus KCTC9752, S. viridodiastaticus IFO13106, S. longispororuber

\section{NBRC13488 and S. paradoxus NBRC14887.}

\subsubsection{Nucleotide Sequence Accession Numbers}

The nucleotide sequences of the isolate ASU319 was deposited in the GenBank nucleotide sequence database under accession number KC145278.

\subsection{Effect of L-glutamine Concentration, Incubation Temperature and $\mathbf{p H}$ on L-glutaminase Production by Streptomyces ASU319.}

The strain Streptomyces ASU319, which produced the highest enzyme, was selected for further investigation to identify the optimal conditions for enzyme production. The effect of L-glutamine concentration was studied by cultivating the strain in production medium supplemented with different concentrations of $\mathrm{L}$ glutamine $(0,1,2,5,7$ and $8 \mathrm{mg} / \mathrm{ml})$. The effect of different temperatures $(20,25,30,35$, 40 and $45{ }^{\circ} \mathrm{C}$ ) on enzyme activity was studied by cultivating the strain in the basal medium supplemented with $2 \mathrm{mg} / \mathrm{ml}$ glutamine and adjusted at $\mathrm{pH}$. The effect of $\mathrm{pH}$ levels $(2,4,6,8$ and 10) was tested in the basal medium supplemented with $2 \mathrm{mg} / \mathrm{ml}$ glutamine and incubated at $30^{\circ} \mathrm{C}$.

\section{Results}

\subsection{Screening for L-glutaminase Production}

A total of 210 actinomycetes isolates were screened for their ability to convert glutamine to ammonia by production of L-glutaminase enzyme. Data presented in Table (1) indicated that a total of $167(79.52 \%)$ isolates have the ability to produce L-glutaminase but 43 (20.47 \%) actinomycetes isolates did not able to produce the enzyme. The producer enzyme isolates were categorized into three groups according to their activity. Among 167 isolates, 132 isolates show low activity, 25 isolates produced moderate activity and the other 10 isolates produced high activity and marked as $(+),(++)$ and $(+++)$, respectively.

Table 1. Primary screening of L-glutaminase biosynthesis by actinomycetes isolates recovered from rhizosphereic soil of wheat (Triticum vulgaris), corn (Zea mays) and broad bean (Vicia faba)

\begin{tabular}{|cccc|c|}
\hline REMARK $^{*}$ & Level & $\begin{array}{c}\text { Number of } \\
\text { isolates }\end{array}$ & Percent & $\begin{array}{c}\text { Total } \\
\text { Number }\end{array}$ \\
\hline & $\begin{array}{c}\text { negativ } \\
\text { e }\end{array}$ & 43 & $20.47 \%$ & 43 \\
+ & Low & 132 & $62.85 \%$ & \\
++ & $\begin{array}{c}\text { Moder } \\
\text { ate }\end{array}$ & 25 & $11.90 \%$ & 167 \\
++ & High & 10 & $4.76 \%$ & \\
\hline
\end{tabular}

*The quantitative standard was according to the diameter of pink zone appeared around the actinomycete colony. It marked as $+(<5 \mathrm{~mm}),++(6-$ $10 \mathrm{~mm})$ and $+++(>10 \mathrm{~mm})$ 
Table 2. Screening of L-glutaminase production by the higher producer actinomycetes isolates

\begin{tabular}{|c|c|c|c|}
\hline Isolates Code & $\begin{array}{l}\text { Location of } \\
\text { isolation }\end{array}$ & $\begin{array}{c}\text { Cultivated } \\
\text { Plant }\end{array}$ & $\begin{array}{c}\text { O. D. } \\
\text { at } 540 \mathrm{~nm}\end{array}$ \\
\hline Streptomyces ASU2 & Assiut & Wheat & 2.522 \\
\hline Streptomyces ASU37 & Assiut-Dairout & Wheat & 2.613 \\
\hline Streptomyces ASU58 & Assiut-Dairout & Wheat & 2.552 \\
\hline Streptomyces ASU147 & $\begin{array}{l}\text { Assiut- } \\
\text { El-Saahell }\end{array}$ & Corn & 3.107 \\
\hline Streptomyces ASU171 & Assiut-Manfalout & Wheat & 2.832 \\
\hline Streptomyces ASU204 & $\begin{array}{c}\text { New Valley- } \\
\text { Barieess }\end{array}$ & Corn & 3.069 \\
\hline Streptomyces ASU216 & $\begin{array}{l}\text { New Valley- } \\
\text { El-kharga }\end{array}$ & Corn & 2.532 \\
\hline Streptomyces ASU266 & $\begin{array}{l}\text { New Valley- } \\
\text { El-Daakhlaa }\end{array}$ & Corn & 2.568 \\
\hline Streptomyces ASU316 & $\begin{array}{l}\text { New Valley- } \\
\text { El-kharga }\end{array}$ & Wheat & 2.582 \\
\hline Streptomyces ASU319 & $\begin{array}{l}\text { New Valley- } \\
\text { El-kharga }\end{array}$ & Wheat & 3.239 \\
\hline
\end{tabular}
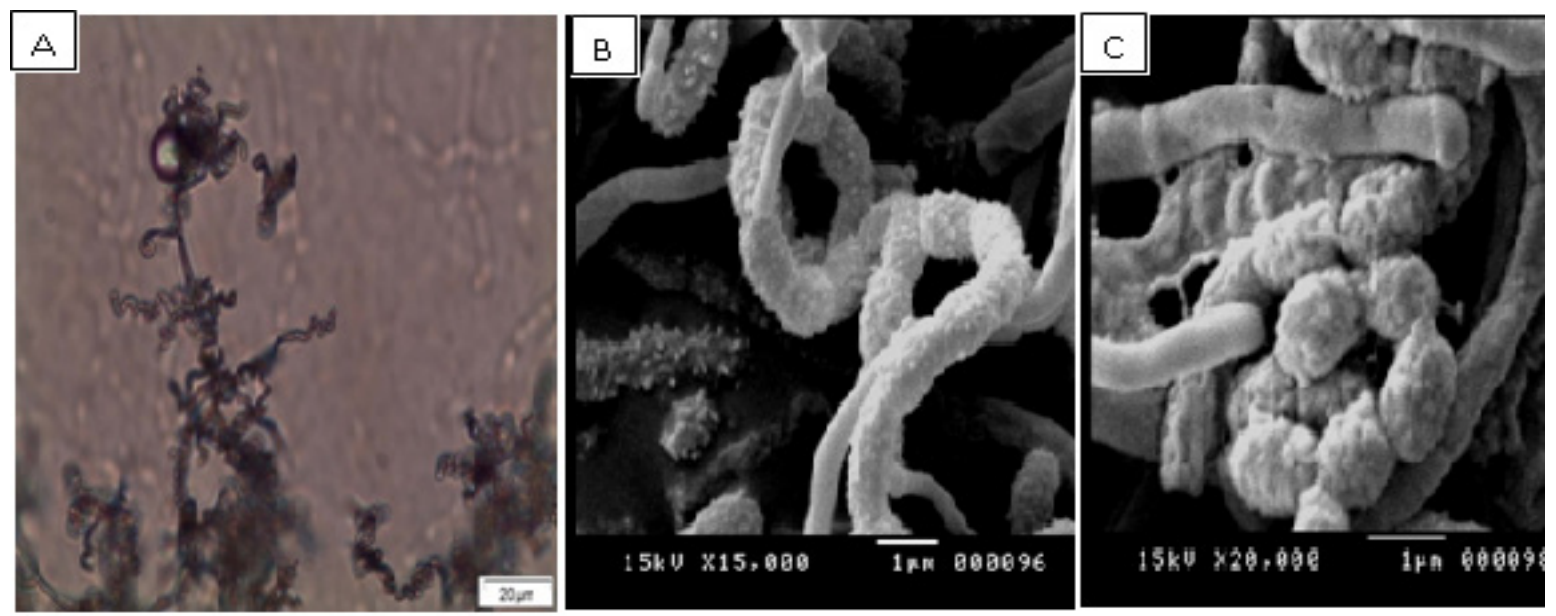

Figure 1. Morphology of the recovered actinomycetes isolate ASU319. A) mycelia and spore chains under light microscope, B\&C) scanning electron micrograph showing spore chain and spore surface.

Table 3. Growth patterns and mycelial colouration of the tested isolate Streptomyces ASU319 on different media

\begin{tabular}{|ccccc|}
\hline Culture Medium & Growth & $\begin{array}{c}\text { Aerial } \\
\text { mycelium }\end{array}$ & $\begin{array}{c}\text { Substrate } \\
\text { mycelium }\end{array}$ & Soluble pigment \\
\hline $\begin{array}{c}\text { Tryptone malt extract agar } \\
\text { (ISP-1) }\end{array}$ & Abundant & Dark grey & Dark brown & Negative \\
$\begin{array}{c}\text { Yeast malt extract agar } \\
\text { (ISP-2) } \\
\begin{array}{c}\text { Oat-meal agar } \\
\text { (ISP-3) }\end{array}\end{array}$ & Fair & Grey & colorless & Negative \\
$\begin{array}{c}\text { Inorganic salts starch agar } \\
\text { (ISP-4) }\end{array}$ & Abundant & Grey & Pale yellow & Negative \\
$\begin{array}{c}\text { Glycerol-Asparagine agar } \\
\text { (ISP-5) }\end{array}$ & Abundant & Light grey & Reddish brown & Negative \\
$\begin{array}{c}\text { Tyrosine agar } \\
\text { (ISP-7) }\end{array}$ & Abundant & Greenish grey & Dark brown & Negative \\
\hline
\end{tabular}


Table 4. Morphological and biochemical characteristics of Streptomyces ASU319

\begin{tabular}{|lc|}
\hline Characteristics & Results \\
\hline Diaminopimelic acid (DAP) & LL-DAP \\
Gram's staining & + \\
Cell morphology & mycelial \\
Spore chain & retinaculum (RA) \\
Spore shape & oval \\
Spore surface & spinous \\
Starch hydrolysis & ++ \\
Cellulose decomposition & ++ \\
Gelatin liquefaction & + \\
H2S production & - \\
Nitrate reduction & + \\
Catalase production & + \\
Milk peptonization & + \\
Melanin production & + \\
Utilization of Carbon & + \\
D-Glucose & + \\
D-Fructose & + \\
D-Galactose & + \\
D-Xylose & + \\
L-Arabinose & + \\
D-Mannitol & + \\
Lactose & + \\
Maltose & + \\
Meso-Inositol & + \\
Rhamnose & + \\
Sucrose & + \\
Utilization of Nitrogen & + \\
L-Glutamine & + \\
L-Tryptophane & + \\
L-Tyrosine & + \\
L-Glycine & + \\
\hline L-Alansine & + \\
\hline
\end{tabular}

+ good, ++ very good, +++ excellent, - negative

\subsubsection{Physiological Properties}

The results presented in Table (4) indicated that the tested isolate was able to hydrolysis starch, decompose cellulose, liquefy gelatin, and produce catalase, but nitrate reduction, milk peptonization and $\mathrm{H}_{2} \mathrm{~S}$ production was negative by this isolate. The tested isolate utilized D-glucose, D-fructose, D-galactose, D-xylose, and sucrose as carbon source for its growth, but it was unable to grow on L-arabinose, Lrhamnose and lactose. Doubtful growth occurred in case of D-mannitol, maltose and meso-inositol. On the other hand, the tested isolate was able to grow on L-glutamine, L-tryptophane, L-tyrosine, L-glycine, L-asparagine, L-cystine, L-phenyl alanine, L-histidine, L-hydroxyproline, and L-lysine as nitrogen source for its growth. Based on the taxonomic characteristics described above, the isolate ASU319 was assigned to the genus Streptomyces.

\subsubsection{Identification and Characterization by $16 \mathrm{~S}$ rRNA Gene Sequences}

The phenotypic-based identification was confirmed by phylogenetic analysis. Comparison between 16S rRNA gene sequence of the tested isolate ASU319 and 16S rRNA gene sequences on GenBank database as determined by using Blast search analysis was done. Sequencing of $16 \mathrm{~S}$ rRNA genes of the tested isolate had 16S rRNA gene with $99 \%$ nucleotides identity to that of Streptomyces variabilis NRRLB3984 available in Genbank database (Fig. 2). The phylogenetic tree was inferred from 16S rRNA sequence data by the neighbor-joining method. The tested isolate was identified as Streptomyces variabilis belongs to family Streptomycetaceae, order Actinomycetales, class Schizomycetes.

\subsection{Optimization of L-Glutaminase Production by Streptomyces Variabilis ASU319}

\subsubsection{Effect of Hydrogen Ion Concentration on L-glutaminase Production}

The effect of different $\mathrm{pH}$ values $(2,4,6,8$ and 10) of the culture medium on the biomass and enzyme production by Streptomyces variabilis ASU319 was investigated. The result revealed that both mycelial growth and enzyme production by Streptomyces variabilis ASU319 was increased gradually with the increase of $\mathrm{pH}$ values reaching maximum at $\mathrm{pH} 4$ for ammonia formation (Fig. 3). However the optimum $\mathrm{pH}$ for bacterial growth was 8 .

\subsubsection{Effect of Incubation Temperature}

Testing the temperature-dependence on mycelia growth and ammonia formation by Streptomyces variabilis ASU319 revealed that $35^{\circ} \mathrm{C}$ was the optimum (Fig. 4). 


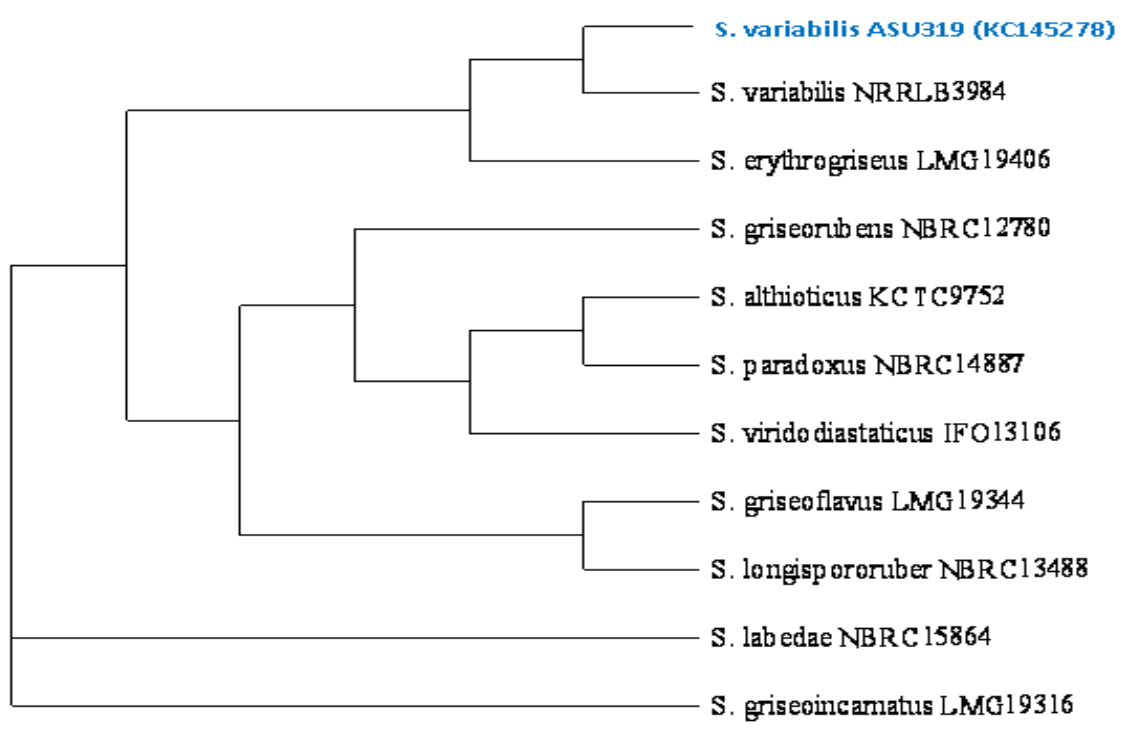

Figure 2. The neighbor-joining tree based on 16S rRNA gene sequences showing the positions of the isolate Streptomyces ASU319 and related strains

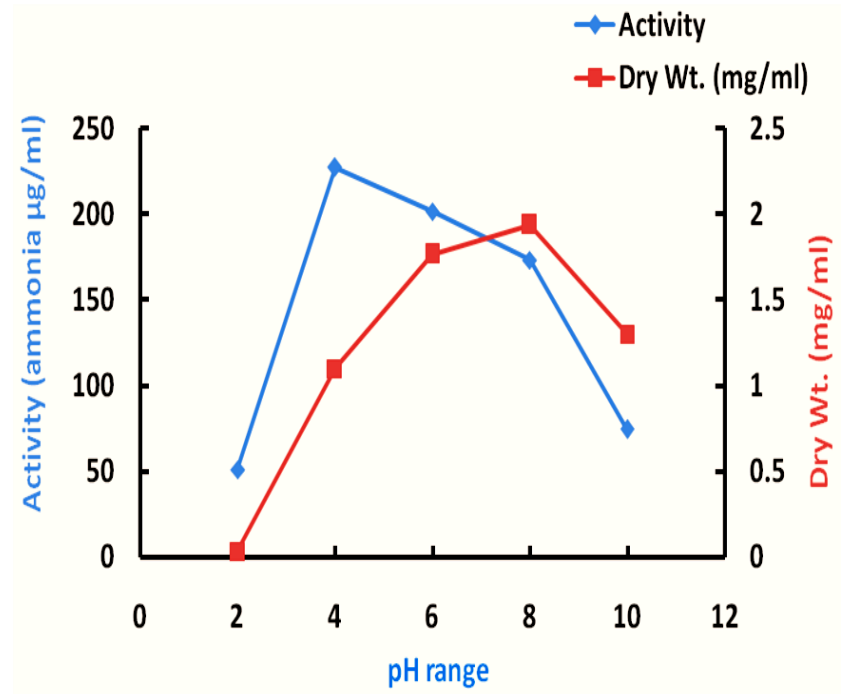

Figure 3. Effect of different $\mathrm{pH}$ values on the dry weight $(\mathrm{mg} / \mathrm{ml})$ and L-glutaminase activity $(\mu \mathrm{g} / \mathrm{ml})$ by Streptomyces variabilis ASU319

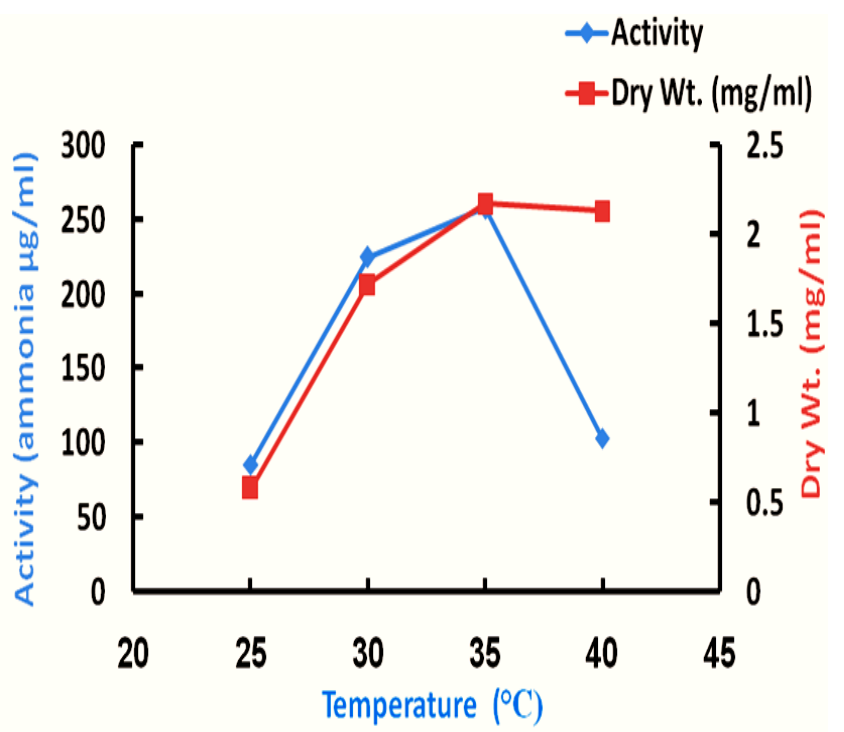

Figure 4. Effect of temperature on the dry weight $(\mathrm{mg} / \mathrm{ml})$ and L-glutaminase activity $(\mu \mathrm{g} / \mathrm{ml})$ by Streptomyces variabilis ASU319 


\subsubsection{Effect of Glutamine Concentration on L-glutaminase} Production

The effect of various concentrations of glutamine on mycelia growth and L-glutaminase production by Streptomyces variabilis ASU319 were investigated and illustrated in Fig. (5). The results indicate that the optimum concentration was $8 \mathrm{mg}$ glutamine per $\mathrm{ml}$ of basal medium.

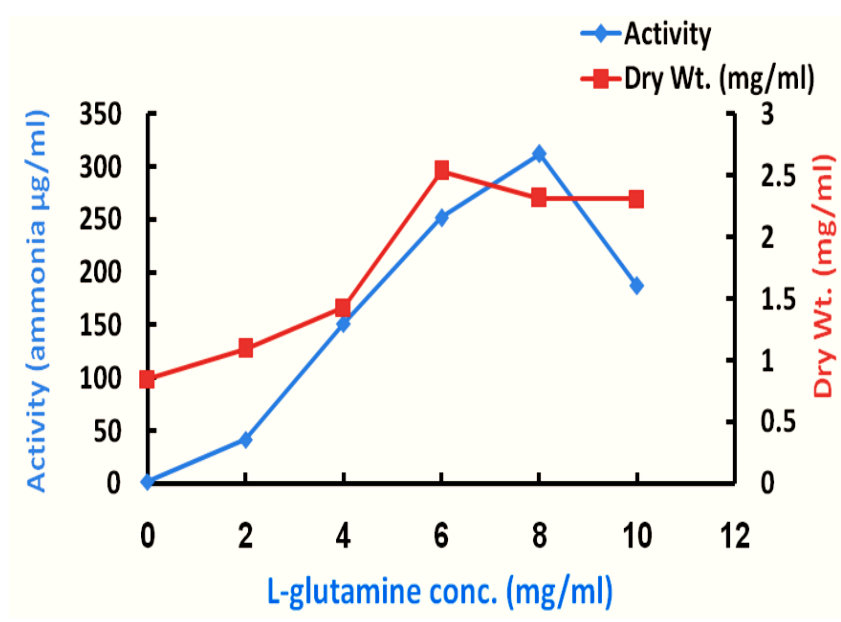

Figure 5. Effect of L-glutamine concentrations on the dry weight $(\mathrm{mg} / \mathrm{ml})$ and L-glutaminase activity $(\mu \mathrm{g} / \mathrm{ml})$ by Streptomyces variabilis ASU319

\section{Discussion}

L-glutamate is one of the substances present in the cultivated soil resulted from the degradation of plants debris, and the bioconversion of this substance by action of enzymes produced from microorganisms especially bacteria will lead to the production of ammonia. This community is supported nutritionally by a high input of organic materials derived from the plant roots and root exudates that are necessary for microbial growth (23). However the composition and quantity of root exudates varies depending on the plant species (24) and the physical environment such as humidity and temperature (25). The absorption of the released ammonia by plant roots will increase of the nitrogen content in the plants. L-glutaminase is the enzyme responsible for conversion of L-glutamine to L-glutamic acid and ammonia, so this enzyme is important in agriculture and potentially useful for stimulating plant growth and increasing crop yields. Another important application of L-glutaminase is in biosensors for monitoring the glutamine levels in mammalian and hybridoma cells. But, from the available literature, it is found that information on L-glutaminase production from actinomycetes is still in the stage of infancy $(6,26)$.

The search for novel L-glutaminase producing actinomycetes and selection of highly producer isolates for commercial and industrial applications are of great interest of the scientists. A total of 210 actinomycetes isolates collected in this study were tested for their ability to produce L-glutaminase in a broth medium supplemented by
L-glutamine as a sole carbon and nitrogen source. L-glutaminase synthesis was well reported from various terrestrial microorganisms such as Escherichia coli, Pseudomonas species, Actinobacter species, Bacillus species, Hansenula, Cryptococcus, Candida, Aspergillus oryzae and Beuveria bassiana $(3,4)$. In addition to terrestrial sources, L-glutaminase activity was reported from few marine microorganisms such as Pseudomonas flourescens, Micrcoccus luteus, Vibrio cholerae, Vibrio cholerae, Vibrio costicola, Beuveria bassiana and Streptomyces spp. (5, 26-31).

Out of 210 actinomycetes isolates recovered in this study, $167(79.52 \%)$ isolates showed positive result in rapid plate assay. In most of the microbial screening programs for enzyme production, the microorganisms are the first isolated from certain environments by routine isolation procedures and then screened for enzymatic activity by methods like zone of color change or zone of clearance on agar medium supplemented with suitable substrate (32). Similar screenings of L-glutaminase production by rapid plate assay were reported in actinomycetes strains (26) and in bacterial cultures (27). Also, similar screening of L-asparaginase by the same method was reported in bacterial strains such as Bacillus circulans (33), Streptomyces sp. PDK7 (34), Streptomyces sp. (35).

Apparently, the most highest producer isolate Streptomyces variabilis ASU319 which of dark grey color and isolated from rhizosphere soil sample cultivated by wheat plant in New Valley governorate, was selected for the optimization of enzyme production . In general, enzymes are measured by estimation of enzyme activity by qualitative estimation $(36,37)$.

Balagurunathan et al. (26) recorded that in his study it was the first report on L-glutaminase producing Streptomyces olivochromogenes in general and marine strains in particular. Also, from the available literatures, we can conclude that it is the first time for the production of L-glutaminase by Streptomyces variabilis. The activity of glutaminase by the tested isolate was determined by estimating the amount of ammonia liberated from glutamine. The isolate Streptomyces variabilis ASU319 exhibited maximum glutaminase activity of $180 \mu \mathrm{g} / \mathrm{ml}$ among all the tested isolates before optimization of the enzyme production by this isolate. This value is higher than the result recorded by (38), they recorded that the maximum value of ammonia in their study was $12.61 \mu \mathrm{g} / \mathrm{ml}$ produced by Streptomyces avermitilis.

Concerning the effect of $\mathrm{pH}$, the results of current research revealed that the optimum $\mathrm{pH}$ for L-glutaminase production and mycelia growth by the tested isolate Streptomyces variabilis ASU319 was at 4 and 8 , respectively. The $\mathrm{pH}$ of the medium plays an important role by inducing morphological changes in microbes and enzyme production.

The maximum L-glutaminase production and mycelia growth were achieved at $35^{\circ} \mathrm{C}$. The incubation temperature is characteristic for the organism and vary for each species (39). Balagurunathan et al. (26) recorded that the maximal activity of the enzyme by Streptomyces olivochromogenes 
was obtained at $\mathrm{pH} 7$ and temperature at $30^{\circ} \mathrm{C}$. Optimum temperature for L-glutaminase production was found to be in range between 25 and $35 \mathrm{oC}$ for the mesophylic microbes (40). Any temperature beyond the optimum range is found to have some adverse on the metabolic activities of the microorganisms and it is also reported by various scientists that the metabolic activities of the microbes become slow at lower or higher temperatures (41).

Concerning the effect of glutamine concentrations, it was found that as the concentration increased the production of L-glutaminase increased till it reached the maximum activity at $8 \mathrm{~g} / \mathrm{l}$. Amino acids were common growth factor required for the synthesis of enzyme as major nitrogen source (42). Since Lglutamine is the substrate of L-Glutaminase, the addition to fermentation medium might stimulate enzyme production. It also serves as source of energy and carbon (43).

The result obtained in the present study indicated that Streptomyces variabilis ASU319 could be a potential actinomycete strain for L-glutaminase production. Optimization of cultural conditions for attaining the high yields of L-glutaminase is very useful for biotechnological application. This isolate Streptomyces variabilis ASU319 exhibited glutaminase production of $180 \mu \mathrm{g} / \mathrm{ml}$ and this value is higher than the other strains. The optimization of growth conditions favor the future large commercial scale production as it maximize the value to more than $300 \mu \mathrm{g} / \mathrm{ml}$ of glutaminase.

\section{Conclusion}

The present study indicated scope for the use of Streptomyces variabilis ASU319 as an ideal actinomycete isolate for the production of extracellular L-glutaminase with maximum activity in the basal medium of $8 \mathrm{~g} / 1$ glutamine, adjusted at $\mathrm{pH} 4$ and incubated at $35^{\circ} \mathrm{C}$ that can be used as plant growth promoting rhizobacteria for enriching the soil fertility across the degradation of the agricultural wastes and increase the nitrogen content in the soil. Also this isolate can be used in both pharmaceutical and food industrial application for L-glutaminase production on commercial scale.

\section{Acknowledgements}

This research was supported by Assuit University Fund.

\section{REFERENCES}

[1] Y. Okami. Marine microorganisms as a source of bioactive agents, Microbiol Ecol, Vol. 12, 56-78, 1986.

[2] M. K. Habeeb. Microbial production of glutaminase enzyme,
J Res Biolo, Vol. 3, 775-779, 2013.

[3] A. Sabu, T. R. Keerthi, S. Rajeev Kumar, M. Chandrasekharan. L-Glutaminase production by marine Beauveria sp. under solid state fermentation, Process Bioch, Vol. 35, 705-709, 2000.

[4] A. Sabu. Sources, properties and applications of microbial therapeutic enzymes, Ind J Biot, Vol. 2, 334-341, 2003.

[5] M. Chandrasekaran. Industrial enzymes from marine microorganisms: Indian scenario, J Mar Biot, Vol. 5,86-89, 1997.

[6] G. Sivakumar, S. Alagumanian, M. V. Rao. High frequency In vitro multiplication of Centella asiatica: An important industrial medicinal herb, Eng Life Sci, Vol. 6, 597-601, 2006.

[7] G. N. Prabhu, M . Chandrasekaran. Impact of process parameters on L-glutaminase production by marine Vibro costicola under solid state fermentation using polystyrene as inert support, Process Bioch, Vol. 32, 285-289, 1997.

[8] G. N. Prabhu, M . Chandrasekaran. Lglutaminase production by marine Vibro costicola under solid state fermentation using different substrates, J Mar Biot, Vol. 4, 176-179, 1996.

[9] G. N. Prabhu, M. Chandrasekaran. Polystyrene an inert carrier for Lglutaminase production by marine Vibrio costicola under solid state fermentation, World J Microbiol Biot, Vol. 11, 683-684, 1995.

[10] C. O. Akujobi, N. N. Odu, S. I. Okorondu, G. N. Ike. Production of protease by Pseudomonas aeruginosa and Staphylococcus aureus isolated from abattoir environment, J Res Biolo, Vol. 2, 077-082, 2012.

[11] L. K. Kenneth. Prepared research paper RP 2911, Central Notations for the Revised ISCC-NBS color name blocks, J Res NBS1, Vol. 6, 427, 1958.

[12] H. D. Tresner, M. C. Davies, E. J. Backus. Electron microscopy of Streptomyces spore morphology and its role in species differentiation, J Bacteriol, Vol. 81, 70, 1961.

[13] C. H. Collins, P. M. Lyne. Microbiological Methods. 5th ed. London: Butterworths; 1985.

[14] T. Hasegawa, M. Takizawa, S. Tanida. A rapid analysis for chemical grouping of aerobic Actinomycetes, J Gen Appl Microbiol, Vol. 29, 319-322, 1983.

[15] W. F. Harrigan, M. F. McCance. Laboratory method in microbiology. London and New York. Academic Press; 1966.

[16] H. Eggins, P. J. F. Pugh. Isolation of cellulose decomposing fungi from the soil, Nature, Vol. 193, 94-95, 1962.

[17] P. H. A. Sneath, V. G. Collins. A study in test reproducibility between laboratories: Report of a Pseudomonas working group, Ant van Leeuwenhoek, Vol. 40, 481-527, 1974.

[18] T. O'reilly, D. F. Day. Effects of culture conditions on protease production by Aeromonas hydrophila, Appl Env Microbiol, Vol. 45, 1132-1135, 1983.

[19] N. W. Schaad. Laboratory Guide for Identification of Plant Pathogenic Bacteria, $2^{\text {nd }}$ Edition, S. t. Paul, APS Press, USA, 1988.

[20] J. F. Bradbury. Isolation and preliminary study of bacteria 
from plants, Rev Plant Path, Vol. 49, 213-218, 1970.

[21] R. Wittenberg. Hydrogen peroxide formation and catalase activity in the lactic acid bacteria, J Gen Microbiol, Vol. 35, 13-14, 1964.

[22] T. G. Pridham, D. Gottlieb. The utilization of carbon compounds by some actinomycetales as an aid for species determination, J Bacteriol, Vol. 56, 107-111, 41948.

[23] M. H. Abd-Alla, F. M. Morsy, A. E. El-Enany, T. Ohyama. Isolation and chatacterization of a heavy-metal-resistant isolate of Rhizobium leguminosrum bv. viciae potentially applicable for biosorption of $\mathrm{Cd}^{2+}$ and $\mathrm{Co}^{2+}$, Int Biodeter Biodegr, Vol. 67, 48-55, 2012.

[24] F. Sanger, S. Nicklen, A. Coulson. DNA sequencing with chain-terminating inhibitors, Proce Nat Acad Sci, Vol. 74, 5463-5467, 1977.

[25] J. M. Lynch. The Rhizosphere, John Wiley \& Sons Ltd, Chichester, 458, 1990.

[26] J. K. Martin, J. R. Kemp. Carbon loss from roots of wheat cultivars, Soil Bio and Bioch, Vol. 12, 551-554, 1980.

[27] W. H. Smith. Character and significance of forest tree root exudates, Ecology, Vol. 57, 324-331, 1976.

[28] R. Balagurunathan, M. Radhakrishnan, S. T. Somasundaram. L-glutaminase producing actinomycetes from marine sediments selective isolation, semi quantitative assay and characterization of potential strain, Aust J Basic Appl Sci, Vol. 4, 698-705, 2010.

[29] T. Prabhakar, K. K. Prasanth, B. Varaprasad, S. G. Girija. Screening of l-glutaminase producing marine bacterial cultures for extracellular production of L-glutaminase, Int $\mathrm{J}$ Che Tech Res, Vol. 1, 1232-1235, 2009.

[30] M. K. Sahu, K. Sivakumar, E. Poorani, T. Thangaradjou, L. Kannan. Studies on L-asparaginase enzyme of actinomycetes isolated from estuarine fishes, J Env Bio, Vol. 28, 465-474, 2007.

[31] S. Renu, M. Chandrasekharan. Extracellular L-glutaminase by marine bacteria, Biot lett; Vol. 14, 471-474, 1992.

[32] M. K. Ranjekar, K. R. Sridhar. Occurrence and extracellular enzymatic potential of actinomycetes of a Thermal spring, Southern India, Asian J Microbiol Biot Env Sci, Vol. 4, 59-64, 2002.

[33] R. S. Prakasham, M. Hymavathi, C. h. Subba Rao, S. K. Arepalli, R. J. Venkateswara, P. Kavin Kennady, K.
Nasaruddin, J. B. Vijayakumar, P. N. Sarma. Evaluation of antineoplastic activity of extracellular asparaginase produced by isolated Bacillus circulans, Appl Bioch Biot, Vol. 160, 72-80, 2010.

[34] P. Dhevagi, E. Poorani. Isolation and characterization of L-asparaginase from marine actinomycetes, Ind J Biot, Vol. 5 , 514-520, 2006

[35] S. N. Basha, R. Rekha, M. Komalal, S. Ruby. Production of extracellular anti-leukaemic enzyme L-asparaginase from marine actinomycetes by solid state and submerged Fermentation: Purification and characterization, Trop J Pharm Res, Vol. 8, 353-360, 2009.

[36] R. Gulati, R. K. Saxena, R. Gupta. A rapid plate assay method for screening L-asparaginase producing microorganisms, Lett Appl Microbiol, Vol. 24, 23-26, 1997.

[37] M. H. Abd-Alla, E. A. El-Sayed, A. M. Rasmey. Indole-3-acetic acid (IAA) production by Streptomyces atrovirens isolated from rhizospheric soil in Egypt, J Biol Earth Sci, Vol. 3(2), 182-193, 2013.

[38] N. A. Abdallah, S. K Amer, M. K. Habeeb. Production, purification and characterization of L-glutaminase enzyme from Streptomyces avermitilis, Afr J Microbiol Res, Vol. 7, 1184-1190, 2013.

[39] M. Chandrasekaran, S. P. Lakshamanaperumal, D. Chandramohan. Combined effect of environmental factors on spoilage bacteria, Fish Tech, Vol. 28, 146-153, 1991.

[40] T. R. Keerthi, P. V. Suresh, A. Sabu, S. Rejeevkumar, M. Chandrasekaran. Extrecellular producrion of L-glutaminasae by alkalophilic Beauveria bassiana BTMF S10 isolated from marine sediment, World J Microbiol Biotechnol, Vol. 15, 751-752, 1999.

[41] R. Tunga, R. Banerjee, B. C. Bhattacharya. Optimization of n-variable biological experiments by evolutionary operation factorialdesign technique, Bioproc Eng, Vol. 20, 485- 489, 1999.

[42] R. Cruz Soto, S. A. Muhammed, C. J. Newbold, C. S. Stewart, R. J. Wallace. Influence of peptides, amino acids and urea on microbial activity in sheep receiving grass hay and on the growth of rumen bacteria in vitro, Animal Feed Sci Tech, Vol. 49, 151-161, 1994.

[43] S. Suresh kumar, R. Muthuvelayudham, T. Viruthagiri. Medium optimization for production of L-Glutaminase (EC 3.5.1.2) by Streptomyces griseus under submerged fermentation, Int J Sci Eng Appl, Vol. 2, 2319-7560, 2013. 